\title{
H2AC1 Gene
}

National Cancer Institute

\section{Source}

National Cancer Institute. H2AC1 Gene. NCI Thesaurus. Code C162884.

This gene is involved in chromatin wrapping. 